\title{
Validation of a South African ruminal protein degradation and UDP digestibility data base for dairy cows
}

\author{
LJ Erasmus 1, PM Botha 1, HH Meissner 2 \\ 1/rene Animal Production Institute, Private Bag X2, Irene $1675 ; 2$ Department Animal and \\ Wildilife Sciences, University of Pretoria, Pretoria 0002, South Africa
}

\begin{abstract}
Although the in situ technique is currently used as the standard method for the determination of protein degradation in most protein evaluation systems for ruminants, these data should be compared with in vivo studies whenever possible. Furthermore, it is often asked whether protein degradability and undegraded dietary protein (UDP) digestibility values of individual feeds may be used to calculate degradability and UDP digestibility of the entire protein in a total mixed diet.
\end{abstract}

Four lactating Holstein cows, fitted with rumen and duodenal cannulae were used in a $4 \times 4$ Latin square design to determine the effect of protein supplement on duodenal $\mathrm{N}$ flow (Erasmus et al, 1994, J Dairy Sci, 77, 36553665). All four diets contained Lucerne hay and Eragrostis curvula hay as roughages and maize meal as primary energy source. Supplemental protein sources were blood meal, maize gluten meal, blood meal plus maize gluten meal, and sunflower meal, which constituted $8,10.5,9.3$ and $13 \%$ of dietary DM respectively. In vivo protein degradability (observed) was estimated as follows : 1 -[(nonammonia $\mathrm{N}$ - microbial $\mathrm{N}) / \mathrm{N}$ intake $]$. These values were compared to in situ database calculated ( $p$ redicted) values.
Furthermore, the mobile bag technique (MBT) was used to determine the UDP digestibility of the total mixed diets (observed) and compared to database calculated values (predicted) using individual feedstuff values. Observed and predicted protein degradability and UDP digestibility values (diets 2 and 4) compared well. The unsatisfactory agreement between observed and predicted UDP digestibility values for diets 1 and 3 can be explained by the high level of blood meal inclusion and different processing of blood meal ; batch dried for data base value and ring dried for in vivo study. If a data base value of $77 \%$ for UDP digestibility of blood meal (Masoero et al, 1994, Anim Feed Sci Technol, 48, 253-263) is used in our calculations, then data base UDP digestibilities would be $77.1 \%$ and $83.3 \%$ respectively for diets 1 and 3 , which is close to the observed in vivo MBT values.

Results suggest that protein degradability and UDP digestibility data base values can be used with confidence by the feed industry. However, proper description of database feedstuffs is essential, especially when chemical or heat processing is involved, since it significantly influences protein degradability and UDP digestibility.

\begin{tabular}{|c|c|c|c|c|c|c|}
\hline \multirow[b]{2}{*}{ Item } & \multirow[b]{2}{*}{$n$} & \multirow[b]{2}{*}{1} & \multicolumn{2}{|c|}{ Diet } & \multicolumn{2}{|r|}{ RPE 1} \\
\hline & & & 2 & 3 & 4 & $(\%)$ \\
\hline Protein degradability (\%) & & & & & & 13.0 \\
\hline Data base & 1 & 52.3 & 51.9 & 52.1 & 73.3 & - \\
\hline In vivo & 4 & $48.1 \mathrm{~b}$ & $48.3^{b}$ & $51.8^{b}$ & $71.9^{\mathrm{a}}$ & - \\
\hline UDP digestibility (\%) & & & & & & 10.9 \\
\hline Data base & 1 & 64.8 & 89.8 & 77.1 & 79.5 & - \\
\hline In vivo $\mathrm{MBT}$ & 4 & $79.9^{b}$ & $90.7 \mathrm{a}$ & $86.9^{a}$ & $78.8^{b}$ & - \\
\hline
\end{tabular}

ab Means in the same line with different superscripts differ $(P<0.05)$.

1 Relative prediction error 